\title{
Defects in the determination of left-right asymmetry
}

\author{
Miranda Penman Splitt, John Burn, Judith Goodship
}

Left and right in the embryo is automatically defined by the formation of the anteroposterior and dorsoventral axes. In an asymmetrical organism, specification of the left-right axis must incorporate two distinct processes, the generation of asymmetry and its orientation or handedness. The orientation of the heart and abdominal organs in vertebrates is non-random and highly conserved both across and within species. ${ }^{1}$ Reversal of orientation may occur without concomitant defects in the generation of asymmetry. However, failure to generate asymmetry is almost always combined with abnormal orientation. The first overt breaking of symmetry across the midline of the embryo occurs when the primitive heart tube loops to the right but subtle asymmetries are evident as early as the primitive streak stage. ${ }^{2}$

A spectrum of malformations, ranging from complete reversed situs to complete failure to establish asymmetry, is seen in man and it is likely that their aetiology and genetic basis will turn out to be extremely heterogeneous. Nevertheless, genetic animal models indicate that a spectrum of lateralisation defects can be produced by a single defective gene. In man most cases of disturbed laterality are sporadic but there are several well recognised syndromes which occur in families.

The usual orientation of the heart and abdominal organs is known as situs solitus. Situs inversus refers to a perfect reversal of situs solitus with a left heart loop. Any arrangement other than situs solitus or situs inversus, that is, random orientation of different organs, is known as heterotaxy or situs ambiguus. The estimated prevalence of complete situs inversus is around 1 in $10000 .^{34} \mathrm{An}$ increased incidence of parental consanguinity has been found, suggesting that a proportion of cases are autosomal recessive. ${ }^{3-5}$ The incidence of heterotaxy is generally much lower, ${ }^{34}$ but interestingly was found to be equal to that of situs interversus in an inbred Bedouin population ( 1 in 4000). ${ }^{6}$

Cardiac anomalies are found in between 3 and $9 \%$ of cases of complete situs inversus. ${ }^{37}$ Heterotaxy, on the other hand, is almost invariably associated with complex cardiovascular malformation as well as splenic and a variety of gastrointestinal anomalies.

In the present state of knowledge, the most logical way to categorise defects in laterality is on the basis of ciliary function.

(F Med Genet 1996;33:498-503)

Key words: asymmetry; laterality defects; isomerism sequence; heterotaxy.

\section{Laterality defects with normal cilia}

The majority of patients with situs inversus or heterotaxy have no symptoms suggestive of ciliary dyskinesia. An important group of these patients have complete absence of visceral asymmetry with evidence for either bilateral left or bilateral right sidedness. This condition is known as isomerism sequence. Other descriptive terms include Ivemark syndrome, asplenia/polysplenia syndrome, and the broader term, laterality sequence.

CLINICAL FEATURES OF ISOMERISM SEQUENCE "Isomerism" refers to the paired structures which usually have morphologically distinct right and left forms, but in this condition are mirror images of each other. Specifically, these are the cardiac atrial appendages, bronchi, and lungs. Thus, in left isomerism sequence the heart has two long narrow atrial appendages and typically both lungs are bilobed with long hyparterial bronchi. In right isomerism sequence both atrial appendages are pyramidal in shape and the lungs are usually trilobed with short eparterial bronchi bilaterally. Many earlier studies do not recognise atrial or bronchial isomerisms as pathological criteria. ${ }^{89}$ Nevertheless, Ivemark ${ }^{8}$ in 1955 realised the importance of the absence of left-right asymmetry in the pathogenesis of the condition and suggested that it be called "asplenia - a teratologic syndrome of visceral symmetry". In recent years it has been shown that isomerism of the atrial appendages is a much more constant feature than the state of the spleen or the presence of heterotaxy. ${ }^{1011}$

There are no population based studies of isomerism sequence. A population based study of asplenia in Canada found the incidence to be 1 per 22000 live births. ${ }^{12}$ Although it includes a few cases of isolated asplenia, it largely excludes cases of left isomerism sequence which is likely to be at least as common. In a retrospective study of children who had undergone cardiac catheterisation, the incidence of complex heart defect with heterotaxy and poly/asplenia was estimated to be $1 / 24000$ in a white English population, accounting for about $1 \%$ of congenital heart disease. ${ }^{13}$ Right isomerism with asplenia appears to be more common in males, ${ }^{1415}$ whereas left isomerism/polysplenia shows an equal sex ratio.

Both left and right isomerism sequence are associated with a wide spectrum of severe heart malformations. ${ }^{1016-18}$ These include anomalies
$M$ Penman Splitt

J Burn

Correspondence to: Dr Penman Splitt. 
The frequency of common heart lesions found in patients with isomerism sequence

\begin{tabular}{lll}
\hline & $\begin{array}{l}\text { Left } \\
\text { isomerism } \\
(\%)\end{array}$ & $\begin{array}{l}\text { Right } \\
\text { isomerism } \\
(\%)\end{array}$ \\
\hline $\begin{array}{l}\text { Interruption of IVC with azygos } \\
\quad \text { continuation }\end{array}$ & 75 & 7 \\
$\begin{array}{l}\text { Total anomalous pulmonary venous } \\
\quad \text { connection }\end{array}$ & 0 & 35 \\
$\begin{array}{l}\text { Common atrium } \\
\text { Single ventricle }\end{array}$ & 47 & 67 \\
Atrioventricular septal defect & 30 & 70 \\
Double outlet right ventricle & 68 & 93 \\
Pulmonary stenosis/atresia & 7 & 47 \\
\end{tabular}

The table refers to the mean of the percentages given in references 10,16 , and 17 for right isomerism and 10,17 , and 18 for left isomerism.

of both systemic and pulmonary venous drainage, which occur as a consequence of atrial isomerism, and malformations which are thought to be secondary to distortion of cardiac looping, septal defects and conotruncal anomalies. The principal defects are summarised in the table. The high incidence of total anomalous pulmonary venous drainage, single ventricle, and pulmonary outflow tract obstruction leads to higher morbidity and mortality in right isomerism sequence. ${ }^{19}$

Patients with right isomerism sequence almost always have asplenia. The converse, that asplenia is usually accompanied by right isomerism, is also true. Anderson et $a l^{11}$ found no instances of complete absence of the spleen without evidence of isomerism of the atrial appendages in a survey of 1042 necropsies. Rarely, patients with right isomerism sequence have between one and four non-uniform spleens. ${ }^{20}$ Antibiotic prophylaxis and pneumococcal vaccination should be standard management in patients with asplenia. Left isomerism sequence is usually accompanied by the presence of multiple (more than six) uniformly sized spleens or spleniculi but patients with smaller numbers of non-uniform spleens are also found. ${ }^{2021}$ Unlike asplenia, polysplenia is found just as frequently without isomerism, either with a normal heart or an isolated heart lesion. ${ }^{22}$ The association of polysplenia with biliary atresia, absent gall bladder, and intestinal malrotation is well recognised. ${ }^{2324}$ Martinez-Frias et $a l^{22}$ also found positive associations between polysplenia and diaphragmatic hernia, cleft lip, hemivertebrae, and agenesis of the corpus callosum.

Intestinal rotation and fixation abnormalities (IRFA) are common: four patients $(14 \%)$ in a series of 28 required emergency surgery for intestinal obstruction. ${ }^{25}$ The authors put the case for routine GI imaging and elective Ladd procedure in cases of isomerism sequence. Hiatus hernia is also a common complication. ${ }^{26}$ Other GI anomalies rarely associated with isomerism sequence include anal stenosis, tracheo-oesophageal fistula, ${ }^{21}$ and annular or short pancreas. ${ }^{2027}$

Anomalies in all other systems are found not uncommonly but are individually rare. ${ }^{2128}$ Phoon and Neill ${ }^{28}$ found genitourinary defects in $11 \%$ of patients with asplenia sequence, the most common being horseshoe kidney and renal hypoplasia. ${ }^{28}$ In the same study $8 \%$ had

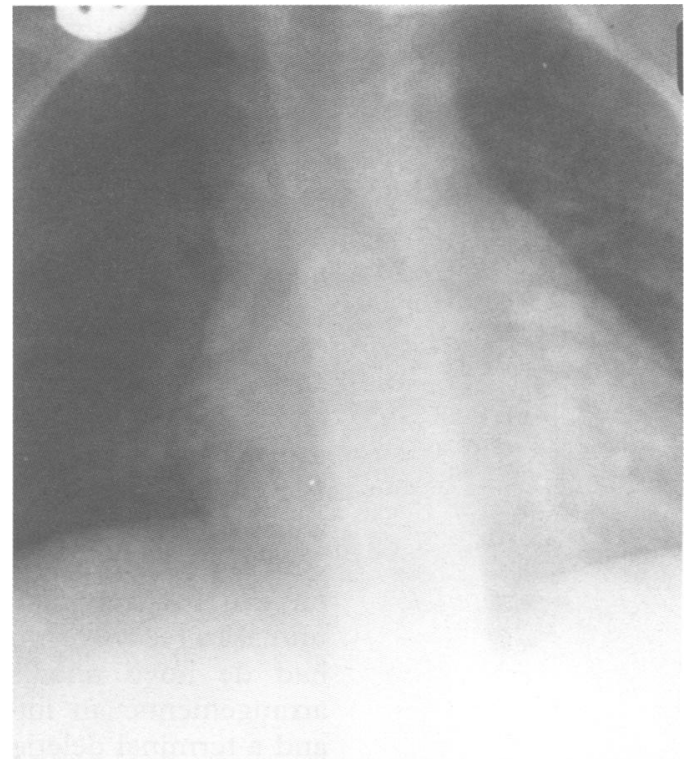

Figure 1 A high kilovoltage filtered chest radiograph showing the bilateral, long hyparterial bronchi of left bronchial isomerism.

musculoskeletal defects, most commonly accessory digits and scoliosis, $6 \%$ facial defects, and $7 \%$ CNS defects. In a review of midline anomalies in 166 patients with isomerism sequence, males accounted for all those cases with imperforate anus and CNS involvement and over $80 \%$ of those with genitourinary and vertebral anomalies ${ }^{29}$ (see section on $\mathrm{X}$ linked laterality disturbance).

Bronchial isomerism can be shown on a high voltage beam chest $x \operatorname{ray}^{30}$ (fig 1). Atrial morphology can be discerned on ultrasound by an experienced cardiologist. Cross sectional views of the abdominal great vessels are said to be very helpful. ${ }^{31}$ MRI may be useful to obtain complete anatomical information. ${ }^{32}$ Abdominal ultrasound should be routine as Howell Jolly bodies cannot always be relied on as a sign of asplenia. ${ }^{16}$

\section{AETIOLOGY AND GENETICS \\ Mouse models}

The best evidence that complete situs inversus, heterotaxy, and isomerism sequence may have the same genetic basis comes from two mouse models: a spontaneous mutant inversus viscerum (iv) $)^{33}$ and an insertional transgenic mutant inversion of embryo turning (inv). ${ }^{34}$

Broadly speaking, situs is random in homozygote $i v / i v$ animals, $50 \%$ having situs solitus and $50 \%$ situs inversus. Heterozygotes are entirely normal. However, more detailed analysis shows that around $30 \%$ of adults have abnormal spleens and venous abnormalities analogous to those commonly found associated with heterotaxy in humans. ${ }^{35}$ Complex cardiac lesions associated with atrial isomerism have been reported in up to $40 \%$ of fetuses. ${ }^{3536} \mathrm{iv}$ has been mapped to the subtelomeric region of mouse chromosome 12 which shows conserved synteny to $14 \mathrm{q}$ in the human. ${ }^{37}$

inv/inv homozygotes all have complete or partial situs inversus, severe jaundice, and kid- 
ney pathology. ${ }^{38} i n v$ is the only known example of a mutation causing consistent reversal of the left-right axis.

\section{Cytogenetic abnormalities}

There are two reports of patients with isomerism sequence and split hand/split foot syndrome associated with apparently balanced chromosomal rearrangements with breakpoints at $7 \mathrm{q} 22.1^{39}$ Wilson et $a l^{40}$ reported a mother and child with an identical apparently balanced translocation with breakpoints at 12q13.1 and $13 \mathrm{p} 13$. The fetus had right isomerism sequence while the mother was entirely normal. $13 \mathrm{p} 13$ contains ribosomal DNA but the breakpoint on 12q13.1 may disrupt a dominant gene or unmask a recessive mutation. Two further cases had de novo unbalanced chromosomal rearrangements: an interstitial deletion of $10 q$ and a terminal deletion of $13 \mathrm{q}^{41}$ There is one report of a case of monosomy 22 who had left isomerism sequence with polysplenia among other abnormalities. ${ }^{42}$ A 22q11.2 deletion has been found in one patient with dextrocardia (I Cross, personal communication) and one patient with left isomerism sequence (S Hodgson, personal communication).

\section{Maternal/environmental factors}

The non-obese diabetic (NOD) mouse is an animal model for insulin dependent diabetes mellitus. Fifty percent of fetuses born to females who were hyperglycaemic and polyuric by early pregnancy were found to have right isomerism sequence. ${ }^{43}$ In man, the association of laterality defects with maternal insulin dependent diabetes is not well recognised. However, in a study from Guy's Hospital, seven out of 102 mothers who had had one child with isomerism sequence were insulin dependent diabetics ( $R$ Yates, personal communication). This is an interesting association given the well known association of caudal regression syndrome with maternal diabetes. Caudal regression is the result of defective development of the posterior notochord. ${ }^{44}$ In Xenopus curtailment of development of dorsal anterior tissue including notochord causes randomisation of heart looping. ${ }^{45}$ Thus the primary problem leading to both laterality defects and caudal regression in the fetuses of diabetic mothers seems to be aberrant development of dorsoanterior midline structures, in particular the notochord.

The earliest investigations of left-right asymmetry relate to twinning. In 1919 , Spemann and Falkenberg produced conjoined twins in newts by mechanical constriction of the embryo. ${ }^{1}$ They found that while the left twin developed normally the right twin had situs inversus in $50 \%$ of cases. This experiment is duplicated very nicely by the observation that in human conjoined twins where the conjunction is lateral or oblique the right twin often has abnormal asymmetry, situs inversus, heterotaxy, or isomerism. ${ }^{46}$ It is likely that the same epigenetic mechanism accounts for the occurrence of isomerism sequence as a discordant trait in monozygous twins. ${ }^{47}$ Indeed, the effect of twinning on the development of left-right asymmetry may be an important factor contributing to the increased incidence of congenital heart defects in monozygous twins. ${ }^{48}$

\section{$X$ linked laterality sequence}

The only locus for heterotaxy to be mapped so far (HTX) is on the X chromosome at Xq24q27.1. ${ }^{49}$ This gene was mapped in a large family where affected males had various cardiac malformations and alterations of visceral situs. In addition, four of the 11 affected males had midline malformations including sacral agenesis, posteriorly placed anus, rectal stenosis, meningomyelocele, cerebellar hypoplasia, and arhinencephaly. The presence of a midline malformation in a male with heterotaxy is highly suggestive of $\mathrm{X}$ linked laterality sequence. ${ }^{50}$ Uterine septa and hypertelorism have been reported as manifestations in carrier females in one family, ${ }^{51}$ and in a second family with apparently $\mathrm{X}$ linked laterality sequence ${ }^{52} \mathrm{fe}-$ males had asymtomatic situs inversus and imperforate anus.

\section{Recessive genes}

The best evidence for an important recessive gene is the high incidence of consanguinity in the parents of affected subjects ${ }^{135^{15-55}}$ and the 10 fold increased incidence of the disorder in an inbred population. ${ }^{13}$ However, the segregation ratio in this population is lower than would be expected for a recessive disorder $(0.09)$ and is very similar to that found by Rose et $a l^{14}$ in their series of Canadian patients. Of course, low penetrance, as in the $i v / i v$ mouse, could account for this but another possibility is that the disease is controlled by two epistatic genes one of which is a rare recessive. Family studies in humans are hampered by lack of large sibships; however there are three reports of large families where laterality sequence appears to be recessive and shows an intrafamilial variability similar to the $i v / i v$ mouse..$^{53557}$ Isolated sib pairs one of whom has isomerism sequence and the other an isolated heart lesion are not uncommon. ${ }^{5860}$ Several sib pairs where both have isomerism sequence have been reported, ${ }^{30}$ seven concordant for right isomerism sequence, three concordant for left, and four discordant, ${ }^{1361-63}$ showing that bilateral left sidedness and bilateral right sidedness may be caused by the same genetic defect. Nevertheless, the uniformity of phenotype in several families in which all affected sibs have right isomerism sequence predicts the existence of a gene causing bilateral right sidedness only.

Recessive mutations in the regulatory domain of the cardiac gap junction protein Connexin 43 have recently been reported in patients with isomerism sequence. ${ }^{64}$ However, we and others have been unable to replicate this finding in over 40 clinically similar patients. ${ }^{65}$

\section{Dominant genes}

A recent report documents a number of families with laterality disturbance where the most likely 


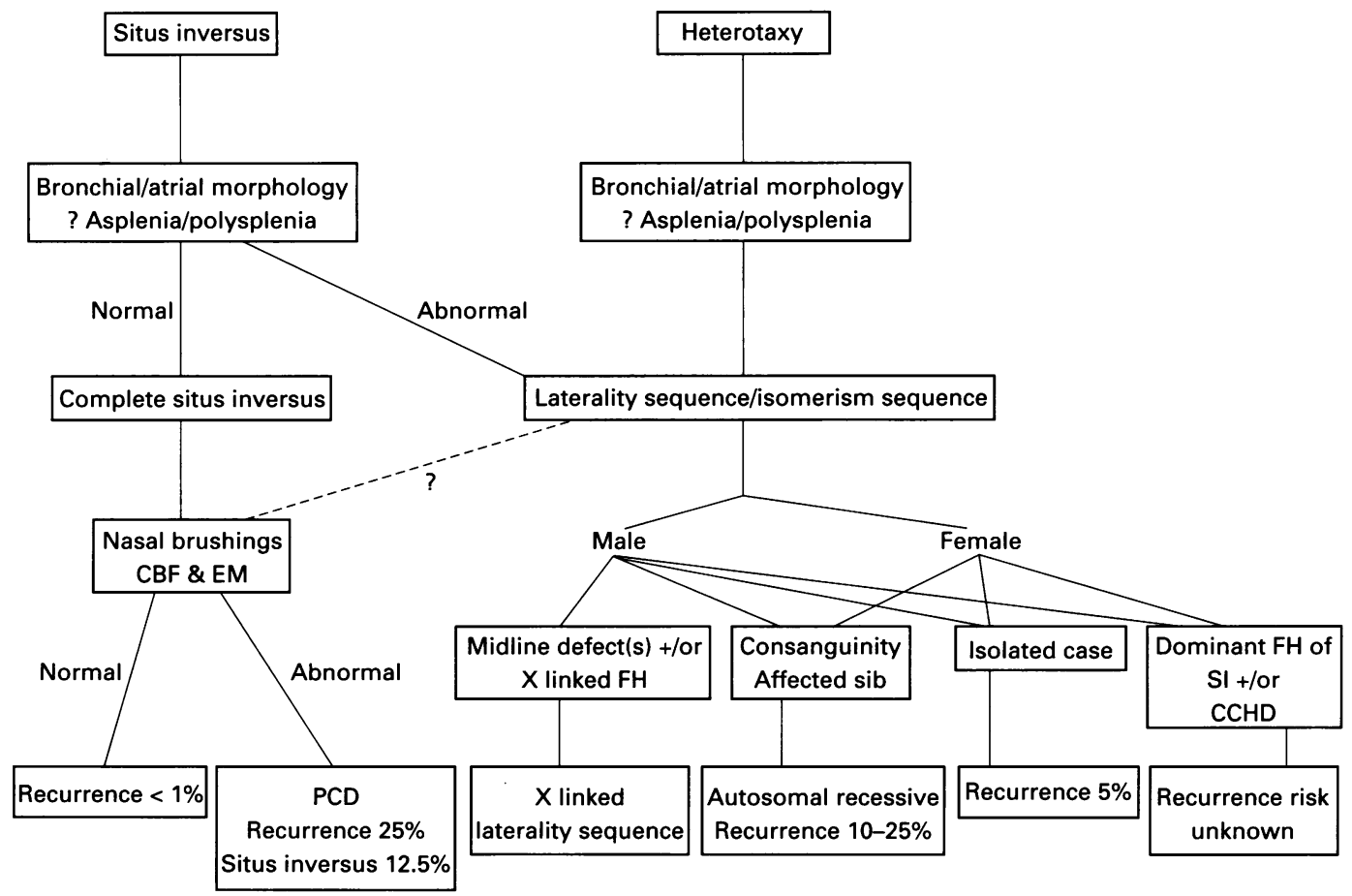

Figure 2 Summary flow diagram for counselling laterality defects. $C B F=$ ciliary beat defect. $E M=$ electron microscopy. $S I=$ situs inversus. $C C H D=$ complex congenital heart defect. $P C D=$ primary ciliary dyskinesia.

form of inheritance is autosomal dominant. ${ }^{66}$ There are several instances of non-penetrance in obligate gene carriers and expression in affected subjects is variable. This highlights the importance of careful pedigree taking in families with an affected child and also suggests that parents should be investigated routinely for evidence of situs inversus. It is possible that some isolated sib pairs will turn out to be the result of germinal mosaicism of new dominant mutations.

\section{Recurrence risks (fig 2)}

In his mass screening of the Norwegian population, Torgersen ${ }^{3}$ found recurrence of situs inversus in sibs in less than $1 \%$ of cases. Interestingly, affected subjects in four of the five families he discovered also had bronchiectasis and nasal polyps suggesting that ciliary dyskinesia accounts for the majority of familial cases of complete situs inversus (see later). An empirical recurrence risk for isomerism sequence of just under $10 \%$ was estimated from a prospective series of over 1000 mothers who were referred for echocardiography because of a previously affected child with congenital heart disease. ${ }^{67}$ One case of isomerism sequence was detected where the index case had a secundum ASD. This is higher than the risk of around 5\% estimated in retrospective studies. ${ }^{1415}$ With improved treatment more children with complex heart lesions are surviving to reproductive age. At present there are no reliable data available from which to estimate recurrence risks in offspring.

Laterality defects with abnormal cilia: primary ciliary dyskinesia

About a quarter of patients with complete situs inversus have primary ciliary dyskinesia (PCD) ( 1 in $30000-40000){ }^{3}$ These patients were ori- ginally described by Kartagener in 1933 as having the triad of situs inversus, sinusitis, and bronchiectasis. ${ }^{68}$ This eponym is no longer appropriate for two reasons. Firstly, while situs inversus is present from birth the other features are secondary to the dyskinetic cilia and may not manifest until much later in $\operatorname{life}^{69}$ and, secondly, in familial cases only $50 \%$ of sibs with dyskinetic cilia have situs inversus. ${ }^{70}$ The cilia in the respiratory epithelium of subjects with PCD are either immotile or dyskinetic leading to chronic respiratory tract infection. ${ }^{7172}$ Demonstration of both functional and ultrastructural changes in the respiratory epithelium is necessary to make the diagnosis. Cilia are most easily obtained by nasal brushings and ciliary beat frequency can be measured videophotometrically. ${ }^{73}$ The most consistent abnormality on electron microscopy is loss of dynein arms, but many other abnormalities have been observed including complete absence of cilia. ${ }^{6971} 74$

\section{CLINICAL FEATURES}

Symptoms and signs are of variable age of onset and severity. Over $90 \%$ of affected subjects are symptomatic in childhood. ${ }^{75}$ Chronic rhinitis leads to sinusitus, opacity of the frontal sinuses, and nasal polyps. Recurrent infection of the lower respiratory tract and middle ear may eventually progress to bronchiectasis, mastoiditis, and conductive deafness. Patients often complain of troublesome headaches. ${ }^{75} \mathrm{De}-$ pressed motility of polymorphic leucocytes has been shown, although bactericidal capacity is normal. ${ }^{76}$ Affected men are usually infertile owing to immotile sperm flagellae but two reports show that this is not invariable. ${ }^{778}$ The spermatozoa are otherwise normal and have been shown to be capable of fusing with and 
fertilising oocytes. Thus in vitro fertilisation in these patients is a possibility. ${ }^{79}$ Women also have reduced fertility, probably because of reduced ciliary movement in the Fallopian tubes. ${ }^{80}$ In a recent series one third of patients with PCD were found to have other congenital malformations.$^{81}$ Heart defects occurred in over $10 \%$. There are reports of patients with polysplenia and biliary atresia and midline defects such as tracheo-oesophageal fistula ${ }^{81-84}$ One of the sibs reported by de la Monte and Hutchins ${ }^{85}$ had left isomerism sequence and polysplenia as well as recurrent purulent rhinorrhoea and chronic tracheobronchitis. This example highlights the possible overlap between laterality defects with and without ciliary dyskinesia. Patients with complex congenital heart disease do not routinely have ciliary biopsies. Ciliary dyskinesia has been shown in asymptomatic patients with situs inversus ${ }^{86}$ and might easily be overlooked in a patient with a heterotaxy. There is certainly a need for further elucidation of a possible common pathogenesis.

\section{AETIOLOGY AND GENETICS}

PCD commonly shows an autosomal recessive inheritance pattern. Fifty percent of affected sibs have situs inversus, suggesting that orientation of lateral asymmetry is random in these people. ${ }^{70}$ As yet, no genes for PCD in man have been mapped. The ciliary axoneme is made up of over 100 polypeptides and dynein itself is a complex protein with several different subunits, so there is likely to be great heterogeneity. ${ }^{87}$ There is one report of a family suggesting either $\mathrm{X}$ linked or autosomal dominant inheritance ${ }^{88}$ Some sporadic cases may be new dominant mutations.

What is the basis of random situs determination in PCD? Afzelius ${ }^{71}$ postulated that normal visceral asymmetry is determined by the coordinated movement of embryonic cilia and that in the absence of ciliary movement situs will be random. However, the presence of ciliary dyskinesia is not a sine qua non for randomisation of situs. The $h p y$ mouse, for example, has immotile cilia, hydrocephalus, and polydactyly but consistently normal situs. ${ }^{89}$ The alternative more plausible hypothesis relates to the fact that dyneins are also present in the cell cytoplasm and control cell polarity. Dyneins are microtubule associated ATPases that induce movement towards the minus end of microtubules. ${ }^{90}$ In lower organisms, for example nematodes, centrosome position, the orientation of spindle formation, and therefore cell cleavage determines cell fate in the first few cell divisions. ${ }^{9192}$ The plane of cleavage is crucial in determining the position of the daughter cells relative to adjacent cells and therefore subsequent cell-cell interactions. In higher organisms, however, "left" and "right" cell fates appear to be unfixed until a much later development stage. ${ }^{93}$

Several candidate loci are suggested by animal models. These include human chromosome $14 \mathrm{q}$ (iv mouse locus) and also incidentally where cytoplasmic dynein heavy chain maps, ${ }^{94}$ chromosome $12 \mathrm{p}$ (syntenic to the $h p y$ mutation on mouse chromosome $6^{89}$ ), and the $\mathrm{X}$ chromosome (the WIC-Hyd rat is an excellent model for human PCD showing $\mathrm{X}$ linked inheritance ${ }^{95}$ ).

\section{Conclusion}

There are still many more questions than answers in our understanding of the molecular basis of laterality disturbance in man. Progress in the elucidation of the genetic basis of leftright asymmetry is likely to come from the study of animal models. The recent exciting discovery that, in frogs and birds, ectopic expression of important signalling molecules such as Wnt, activin, and Sonic hedgehog result in random heart looping represents the start of this process. ${ }^{96}$

1 Brown NA, Wolpert L. The development of handedness in left/right asymmetry. Development 1990;109:1-9.

2 Cooke J. Vertebrate embryo handedness. Nature 1995;374 681 .

3 Torgersen J. Genic factors in visceral asymmetry in the development and pathological changes of the lungs, heart and abdominal organs. Arch Pathol 1949;47:556-93.

4 Campbell $M$. The mode of inheritance in isolated laevocardia and dextrocardia and situs inversus. Br Heart $\mathcal{f}$ 1963;25:803-13.

5 Cockayne EA. The genetics of transposition of the viscera. $Q \mathcal{F}$ Med 1983;31:479-93.

6 Uma R, Usha R, Tahseen SK, Al-Ghanin M, Farag TI Dextrocardia $+1-$ situs inversus among Bedouins. British Medical Genetics Conference, York, 1995:A55(abstract).

7 Merklin RJ, Varano NR. Situs inversus and cardiac defects. A study of 111 cases of reversed asymmetry. 7 Thorac Cardiovasc Surg 1995;45:334-42.

8 Ivemark BI. Implications of agenesis of the spleen on the pathogenesis of conco-truncus anomalies in childhood. Acta Paediatr Scand 1955;44:1-110.

9 Ruttenberg HD, Neufeld HN, Lucas RV, et al. Syndrome of congenital cardiac disease with asplenia. Am $\mathcal{F}$ Cardiol of congenital cardiac

10 Ho SY, Cook A, Anderson EH, Allan LD, Fagg N. Isomerism of the atrial appendages in the fetus. Pediatr Pathol 1991;11:589-608.

11 Anderson C, Devine WA, Anderson RH, Debich DE, Zuberbuhler JR. Abnormalities of the spleen in relation to congenital malformations of the heart: a survey of necropsy findings in children. Br Heart $\mathcal{f} 1990 ; 63: 122-8$.

12 Webber SA, Sandor GGS, Patterson MWH, et al. Prognosis in asplenia syndrome - a population based review. Cardio Young 1992;2:129-35.

13 Gatrad AR, Read AP, Watson GH. Consanguinity and complex cardiac anomalies with situs ambiguus. Arch Dis Child 1984;59:242-5.

14 Rose V, Izukawa T, Moes CAF. Syndromes of asplenia and polysplenia: a review of cardiac and noncardiac malpolysplenia: a review of cardiac and noncardiac maland prognosis. Br Heart $\mathcal{F} 1975 ; 37: 840-52$.

15 Burn J, Coffey R, Allan LD, Robinson P, Pembrey ME, urn J, Coffey R, Allan LD, Robinson P, Pembrey ME, Macartney FJ. Isomerism: a genetic analysis. In: Doyle eds. Paediatric cardiology. New York: Springer Verlag, 1986: eds. Paediatric cardiology. New York: Springer Verlag, 1986: $1126-8$

16 Chiu I, How S, Wang J, et al. Clinical implications of atria isomerism. Br Heart $\mathcal{F} 1988 ; 60: 72-7$.

7 Sapire DW, Ho SY, Anderson RH, Rigby ML. Diagnosis and significance of atrial isomerism. Am $\mathcal{f}$ Cardiol 1986; 58:342-6.

18 Sharma S, Devine W, Anderson RH, Zuberbuhler JR. Identification and analysis of left atrial isomerism. Am f Cardiol 1987;60:1157-60.

19 Phoon CK, Neill CA. Asplenia syndrome - risk factors for early unfavorable outcome. Am f Cardiol 1994;73:1235-7.

20 Landing BH. Five syndromes (malformation complexes) of pulmonary symmetry, congenital heart disease, and of pulmonary symmetry, congenital heart diseas

21 Peoples WM, Moller JH, Edwards JE. Polysplenia: a review of 146 cases. Pediatr Cardiol 1983;4:129-37.

22 Martinez-Frias ML, Urioste M, Bermejo E, et al. Primary midline developmental field. II. Clinical/epidemiological midline developmental field. II. Clinical/epidemiological analysis of alteration of laterality (normal body symm

23 Carmi R, Magee CA, Neill CA, Karrer FM. Extrahepatic biliary atresia and associated anomalies: etiologic heterogeneity suggested by distinctive patterns of associations. Am $\mathcal{F}$ Med Genet 1993;45:683-93.

24 Chandra RS. Biliary atresia and other structural anomalies in the congenital polysplenia syndrome. $\mathcal{F}$ Pediatr 1974; 85:649-55.

25 Chang J, Brueckner $M$, Touloukian RJ. Intestinal rotation and fixation abnormalities in heterotaxia: early detection and management. $\mathcal{F}$ Pediatr Surg 1993;28:1281-5.

26 Wang J, Chang $M$. Association of hiatus hernia with asplenia syndrome. Am f Cardiol 1995;75:317.

27 Wainwright $\mathrm{H}$, Nelson $\mathrm{M}$. Polysplenia syndrome and congenital short pancreas. Am f Med Genet 1993;47:318-20. 
28 Phoon CK, Neill CA. Asplenia syndrome: insight into embryology through an analysis of cardiac and extracardiac anomalies. $\mathrm{Am}$ f Cardiol 1994;73:581-7.

29 Evans JA, Greenberg CR, Chudley AE. Midline anomalies in individuals with asplenia. Proceedings of the David Smith Workshop on Malformations 1993(abstract).

30 Burn J. Disturbance of morphological laterality in humans. In: Bock GR, Marsh J, eds. Biological asymmetry and In: Bock GR, Marsh J, eds. Biological asym

31 Huhta JC, Smallhorn JF, Macartney FJ. Two dimensional echocardiogaphic diagnosis of situs. Br Heart $\mathcal{f} 1982 ; 48$ :

32 Wang JK, Li YW, Chiu IS, et al. Usefulness of magnetic resonance imaging in the assessment of venoatrial connections, atrial morphology, bronchial situs, and other anomalies in right atrial isomerism. Am $\mathcal{F}$ Cardiol 1994; 74:701-4

33 Hummel KP, Chapman DB. Visceral inversion and associated anomalies in the Mouse. 7 Hered 1959;50:9-13.

34 Yokoyama T, Copeland NG, Jenkins NA, et al. Reversal of left-right asymmetry: a situs inversus mutation. Science 1993;260:679-82.

35 Seo J, Brown NA, Ho SY, Anderson RH. Abnormal laterality and congenital cardiac anomalies, relations of visceral and cardiac morphologies in the iv/iv mouse. Circulation 1993; 86:642-50.

36 Icardo JM, Sanchez de Vega MS. Spectrum of heart malformations in mice with situs solitus, situs inversus and associated visceral heterotaxy. Circulation 1991;84:254758.

37 Brueckner M, D'Eustachio P, Horwich AL. Linkage mapping of mouse gene, iv, that controls left-right asymmetry of the heart and viscera. Proc Natl Acad Sci USA 1989; 86:5035-8.

38 Morishima M, Miyagawa-Tomita S, Takao A, Ishibashi M, Yokoyama T, Overbeek PA. Morphological study of the inv situs inversus mutant mouse. In: Clark EB, Markwald inv situs inversus mutant mouse. In: Clark EB, Markwald $\mathrm{RR}$, Takao A, eds. Developmental mechanisms of heart
ease. New York: Futura Publishing Co, 1995;621-4

39 Genuardi M, Gurrieri F, Neri G. Genes for split hand/split foot and laterality defects on $7 \mathrm{q} 22.1$ and Xq24-q27.1. Am f Med Genet 1994;50:101.

40 Wilson GN, Stout JP, Schneider NR, Zneimer SM, Gilstrap LC. Balanced translocation $12 / 13$ and situs abnormalities: homology of early pattern formation in man and lower organisms? Am F Med Genet 1991;38:601-7.

41 Carmi R, Rosenbaum KR. Human situs determination is probably controlled by several different genes. Am F Med Genet 1992;44:246-7.

42 DeCicco F, Steele MW, Pan S, Park SC. Monosomy of chromosome no 22: a case report. $\mathcal{F}$ Pediatr 1973;83. 836-8.

43 Morishima M, Miura S, Ando M, Takao A. Visceroatrial heterotaxy syndrome in the nonobese diabetic mouse. In: Clark EB, Takao A, eds. Developmental cardiology: morphogenesis and function. Mount Kisco, New York: Futura 1990:431-41.

44 Lynch S, Bond P, Copp A, et al. A gene for autosomal dominant sacral agenesis maps to the holoprosencephaly region at $7 \mathrm{q} 36$. Nature Genet 1995;11:93-5.

45 Danos MC, Yost HJ. Linkage of cardiac left-right asymmetry and dorsal anterior development in Xenopus. Development 1995;121:1467-74.

46 Rossi MB, Burn J, Ho SY, et al. Conjoined twins, right atrial isomerism, and the sequential analysis. Br Heart $\mathrm{f}$ 1987;58:518-24.

47 Wilkinson JL, Holt PA, Dickinson DF, Jivani SK. Asplenia syndrome in one of monozygotic twins. Eur $\mathcal{f}$ Cardiol $1979 ; 10: 3-1-304$

48 Burn J, Corney G. Congenital heart defects and twinning. Acta Genet Med Gemellol 1984;33:61-9.

49 Casey B, Devoto M, Jones KL, Ballabio A. Mapping a gene for familial situs abnormalities to human chromosome Xq24-q27.1. Nature Genet 1993;5:403-7.

50 Fullana A, Garcia-Frias E, Martinez-Frias ML, Razquin S, Quero J. Caudal deficiency and asplenia anomalies in sibs. Am $\mathcal{F}$ Med Genet 1986;suppl 2:23-9.

51 Mikkilä SP, Janas M, Karikoski R, Tarkkila T, Simola $\mathrm{KOJ}$. X-linked laterality sequence in a family with carrier manifestations. Am 7 Med Genet 1994;49:435-8.

52 Casey B, Gebbia M, Devoto M, Nelson DL, Aylsworth AS Females with midline malformations and complex reversal of left-right asymmetry in a family with X-linked heterotaxy. Am 7 Hum Genet Suppl 1995;57:A85.

53 Arnold GL, Bixler D, Girod D Probable autosomal recessive inheritance of polysplenia, situs inversus and cardiac defects in an Amish family. Am $\mathcal{F}$ Med Genet 1983 16:35-42.

54 Distefano G, Romeo MG, Grasso S, et al. Dextrocardia with and without situs viscerum inversus in two sibs. $A m$ f Med Genet 1987;27:929-34

55 Schönfeld EA, Frischman B. Syndrome of spleen agenesis, defects of the heart and vessels and situs inversus. Helv Paediatr Acta 1958;6:636-40.

56 Zlotogora J, Schimmel MS, Glaser Y. Familial situs inversus and congenital heart defects. Am $\mathcal{F}$ Med Genet 1987;26: $181-4$

57 Czeizel A. Familial situs inversus and congenital heart defects. Am F Med Genet 1987;28:227-8.

58 Silver W, Steier M, Chandra N. Asplenia syndrome with congenital heart disease and tetralogy of Fallot in siblings. Am 7 Cardiol 1972;30:91-4.

59 Katcher AL. Familial asplenia, other malformations, and sudden death. Pediatrics 1980;65:633-5.
60 Fuhrmann W. Congenital heart disease in sibships ascertained by two affected siblings. Humangenetik 1968;6: $1-12$.

61 Polhemus DW, Schafer WG. Congenital absence of the spleen: syndrome with atrioventricularis and situs inversus. Pediatrics 1952;9:696-708.

62 Zlotogora J, Elian E. Asplenia and polysplenia syndromes with abnormalities of lateralisation in a sibship. $7 \mathrm{Med}$ Genet 1981;18:301-2.

63 Niikawa N, Kohsaka S, Mizumoto M, Hamada I, Kajii T. Familial clustering of situs inversus totalis, and asplenia and polysplenia syndromes. Am $\mathcal{F}$ Med Genet 1983;16: 43-7.

64 Britz-Cunningham SH, Shah MM, Zuppan CW, Fletcher WH. Mutations of the Connexin 43 gap-junction in patients with heart malformations and defects of laterality. $N$ Engl f Med 1995;332:1323-9.

65 Penman Splitt M, Burn J, Goodship J. Connexin 43 mutations in sporadic and familial defects of laterality. $\mathrm{N} \mathrm{Engl} 7 \mathrm{Med}$ 1995;333:941.

66 Alonso S, Pierpont ME, Radtke W, et al. Heterotaxia syndrome and autosomal dominant inheritance. $\mathrm{Am} \mathcal{F} \mathrm{Med}$ Genet 1995;56:12-15.

67 Allan LD, Crawford DC, Chita SK, Anderson RH, Tynan MJ. Familial recurrence of congenital heart disease in a prospective series of mothers referred for fetal echocardiography. Am f Cardiol 1986;58:334-7.

68 Kartagener M. Stucki P. Bronchiectasis with situs inversus. Arch Pediatr 1962;79:193-207.

69 Sturgess JM, Thompson MW, Czegledy-Nagy E, Turner JAP. Genetic aspects of immotile cilia syndrome. Am $\mathcal{F}$ Med Genet 1986;25:149-60.

70 Moreno A, Murphy EA. Inheritance of Kartagener's syndrome. Am $\mathcal{F}$ Med Genet 1981;8:305-15.

71 Afzelius BA. A human syndrome caused by immotile cilia. Science 1976;193:317-19.

72 Rossman CM, Forrest JB, Lee RMK, Newhouse MT. The dyskinetic cilia syndrome: ciliary motility in the immotile cilia syndrome. Chest 1983;78:580-2.

73 Rutland J, Cole PJ. Non-invasive sampling of the nasal cilia for measurement of beat frequency and study of ultrastructure. Lancet 1980;ii:564-5.

74 Rott HD. Kartagener's syndrome and the syndrome of immotile cilia. Hum Genet 1979;46:249-61.

75 Afzelius BA. The immotile-cilia syndrome and other ciliary diseases. Int Rev Exp Pathol 1979;19:1-43.

76 Valerius NH, Knudsen BB, Pedersen M. Defective neutrophil motility in patients with primary ciliary dyskinesia. Eur $\mathcal{F}$ Clin Invest 1983;13:489-94

77 Jonsson MS, McCormick JR, Gillies CG, Gondos B. Kartagener's syndrome with motile spermatozoa. $N$ Engl f Med 1982;307:1131-3.

78 Samuel I. Kartagener's syndrome with normal spermatozoa. $7 A M A$ 1987;258:1329-30.

79 Aitken RJ, Ross A, Lees MM. Analysis of sperm function in Kartagener's syndrome. Fertil Steril 1983;40:696-8.

$80 \mathrm{McComb}$ P, Langley L, Villalon M, Verdugo P. The oviduct cilia and Kartagener's syndrome. Fertil Steril 1986;46: 412-16.

81 Engesaeth VG, Warner JO, Bush A. New associations of primary ciliary dyskinesia syndrome. Pediatr Pulmonol 1993;16:9-12.

82 Teichberg S, Markowitz J, Silverberg M, et al. Abnormal cilia in a child with the polysplenia syndrome and extrahepatic biliary atresia. F Pediatr 1982;100:399-40

83 Schidlow DV, Katz SM, Turtz MG, Donner RM, Capasso S. Polysplenia and Kartagener syndromes in a sibship: association with abnormal respiratory cilia. $f$ Pediatr 1982 ; 100:401-3.

84 Gershoni-Baruch R, Gottfried E, Pery M, Sahin A, Etzioni A. Immotile cilia syndrome including polysplenia, situs inversus, and extrahepatic biliary atresia. Am $\mathcal{F}$ Med Genet 1989;33:390-3.

85 de la Monte SM, Hutchins GM. Brief clinical report. Sisters with polysplenia. Am $\mathcal{F}$ Med Genet 1985;21:171-3.

86 Kroon AA, Hiej JMH, Kuijper WA, Veerman AJP, van der Baan S. Function and morphology of respiratory cilia in situs inversus. Clin Otolaryngol 1991;16:294-7.

87 Afzelius BA. Genetical and ultrastructural aspects of the immotile-cilia syndrome. Am F Hum Genet 1981;33:852-

88 Narayan D, Krishnan SN, Upender $M$, et al. Unusual inheritance of primary ciliary dyskinesia (Kartagener's syndrome). $\mathcal{F}$ Med Genet 1994;31:493-6.

89 Bryan JHD. The immotile cilia syndrome. Mice versus man. Virchows Arch 1983;399:265-75.

90 McIntosh JR, Porter ME. Enzymes for microtubule-dependent motility. F Biol Chem 1989;264:6001-4.

91 Priess JR. Establishment of initial asymmetry in early Caenorhabditis elegans embryos. Cur Opin Genet Dev 1994;4:563-8.

92 Rhyu MS, Knoblich JA. Spindle orientation and asymmetric cell fate. Cell 1995;82:523-6.

93 Hoyle C, Brown NA, Wolpert L. Development of left/right handedness in the chick heart. Development 1992;115: $1071-8$

94 Narayan D, Desai T, Banks A, et al. Localization of the human cytoplasmic dynein heavy chain (DNECL) to 14 qter by fluorescence in situ hybridization. Genomics 1994;22:660-1.

95 Torikata C, Kijimoto C, Koto M. Ultrastructure of respiratory Cilia of WIC-Hyd male rats. Am F Pathol 1991; 138:341-7.

96 Yost HJ. Vertebrate left-right development. Cell 1995;82 689-92. 